\author{
Agnieszka Kłosińska-Nachin \\ Uniwersytet Łódzki \\ Katedra Filologii Hiszpańskiej
}

\title{
DZIENNIKARSTWO I LITERATURA W HISZPANII - KRÓTKA (I WYBIÓRCZA) HISTORIA ZWIĄZKÓW
}

Celem artykułu jest analiza związków między dziennikarstwem a literaturą hiszpańską w perspektywie historycznej. Od początku swego istnienia dziennikarstwo w Hiszpanii było silnie związane $\mathrm{z}$ literaturą, a obydwie dziedziny stanowiły dla siebie wzajemną inspirację. Twórczość pisarzy-dziennikarzy, takich jak Mariano José de Larra, Benito Pérez Galdós, Miguel de Unamuno, Azorín, Miguel Delibes, Javier Cercas czy Juan José Millás, może być właściwie zrozumiana, jeśli weźmie się pod uwagę ich działalność dziennikarską. W ostatnich dziesięcioleciach opisywane relacje uległy zacieśnieniu, czego dowodem może być powieść non-fiction zatytułowana El impostor (2014) Javiera Cercasa.

Słowa kluczowe: dziennikarstwo, literatura hiszpańska, cenzura, funkcja etyczna, non-fiction

\section{Summary}

Journalism and literature in Spain - short and (selective) history of relationships

The aim of this article is to analyze relationships between journalism and Spanish literature in the historical perspective. From the beginning of its existence journalism in Spain has been closely connected with literature and both spheres represented inspiration for one another. The output of such writers-journalists as Mariano José de Larra, Benito Pérez Galdós, Miguel de Unamuno, Azorín, Miguel Delibes, Javier Cercas or Juan José Millás may be properly understood only if one considers their journalistic writing. In recent decades the relationships in question have tightened, a proof of which may be El impostor (2014), a non-fiction novel by Javier Cercas.

Keywords: journalism, Spanish literature, censorship, ethical function, non-fiction

Historia związków między dziennikarstwem a literaturą w Hiszpanii sięga początków dziennikarstwa, czyli XVIII wieku. Przez kolejne dziesięciolecia związki te ulegały zacieśnieniu, wzajemnie determinując ekspresję literacką z jednej strony i dziennikarską z drugiej. W historii przenikania się tych dwóch dziedzin niezwykle istotne okazało się funkcjonowanie w warunkach cenzury, która narzuciła zarówno prasie, jak i literaturze szereg strategii tekstualnych mających 
na celu uniknięcie zakazu publikowania. Jednocześnie ostatnie dekady pokazują, że proza hiszpańska coraz chętniej sięga do metod badania rzeczywistości typowych dla dziennikarstwa, co uwidacznia powieść non-fiction ( $\sin$ ficción), podobnie jak refleksja na temat tego typu literackiej ekspresji, nierzadko zresztą prezentowana - co znamienne - na łamach prasy codziennej. Niniejszy artykuł stawia sobie za cel nakreślenie historii tych nadzwyczaj płodnych związków między dziennikarstwem a literaturą w Hiszpanii.

Zanim jednak przejdę do rozwinięcia tego tematu, słów kilka na temat procesu wyłaniania się interesującej mnie problematyki w perspektywie badawczej. Refleksja dotycząca literackości dziennikarstwa pojawiła się w pierwszej połowie XIX wieku. W 1845 roku pisarz i polityk Joaquín Francisco Pacheco w swoim przemówieniu wygłoszonym z okazji przyjęcia w poczet hiszpańskich akademików mówił o konieczności rozpatrywania dziennikarstwa jako dziedziny literatury ${ }^{43}$. Od drugiej połowy XIX wieku mnożyły się podobne postulaty, których przykładem jest stanowisko wyrażone w Enciclopedia moderna, wydanej przez Francisca de Paula Mellado (1851-1855). Za hasłem „dziennikarstwo” pojawia się w nawiasie słowo „literatura”, która według autorów dzieli się na dwie duże kategorie: pierwsza, o charakterze monumentalnym i wiecznym, druga, z natury efemeryczna i okolicznościowa. Dziennikarstwo należy do tej drugiej gałęzi literatury ${ }^{44}$. Jednak pomimo tych głosów oraz oczywistej - jak zobaczymy - kontaminacji między badanymi dziedzinami pisarstwa, przez długie dziesięciolacia XIX wieku literacki charakter dziennikarstwa był przedmiotem polemiki, widocznej w szczególności w hiszpańskich traktatach retoryki ${ }^{45}$. Jednocześnie nieliczne są dziewiętnastowieczne podręczniki literatury, które wspominają o twórczości dziennikarskiej autorów takich, jak Mariano José de Larra. Spór o literackość dziennikarstwa nieobcy był również XX wiekowi, choć przyniósł on ostatecznie akceptację ze strony akademii tzw. dziennikarstwa literackiego, które wykrystalizowało się w Hiszpanii wokół dwóch dużych kategorii: tradycyjnie dominującego dziennikarstwa opartego na komentarzu do bieżących wydarzeń (na przykład kronika czy felieton) oraz dziennikarstwa zawierającego komponentę narracyjną (na przykład reportaż) ${ }^{46}$. I tak na przykład w 1953 roku Nicolás González Ruiz otwarcie krytykował amerykańskich badaczy podkreślających różnice między literaturą i dziennikarstwem,

43 Zob. A. Mancera Rueda, El periodismo en las preceptivas literarias de los siglos XIX y XX, „Dicenda. Cuadernos de Filología Hispánica” 2011, vol. 29, s. 231.

44 Enciclopedia moderna. Diccionario universal de literatura, ciencias, artes, agricultura, industria y comercio, ed. F. de Paula Mellado, t. 30, Madrid 1954, s. 39-40.

45 Zob. A. Mancera Rueda, El periodismo...

46 Zob. F. López Pan, Periodismo literario: entre la literatura constitutiva y la condicional, „Ámbitos” 2010, vol. 19, s. 98. 
argumentując, że „narracja dziennikarska jest częścią narracji literackiej” ${ }^{47}$, zaś Gonzalo Martín Vivaldi przepowiadał w 1973 roku, że przyszłość należy do gazet, do których będą pisać dziennikarze-literaci ${ }^{48}$. Jednak wbrew tej przepowiedni lata siedemdziesiąte XX wieku to wyraźny krok wstecz w procesie legitymizacji hiszpańskiego dziennikarstwa literackiego. Wyodrębnienie dziennikarstwa jako osobnego kierunku uniwersyteckiego skłoniło bowiem część akademii do izolowania tej sfery jako autonomiczej dziedziny pisarstwa, dla której literatura, a w szczególności łączony z nią subiektywizm perspektywy, niosła szereg zagrożeń. Takie stanowisko reprezentuje chociażby Martínez Albertos ${ }^{49}$. Na przełamanie barier zarówno ze strony dziennikarzy, jak i przedstawicieli świata literatury trzeba było poczekać aż do ostatnich dziesięcioleci XX wieku, bowiem dopiero książka Periodismo informativo de creación Sebastiána Bernala i Luisa Alberta Chillóna z 1985 roku oraz kolejne prace Chillóna ${ }^{50}$ - podważając zasadność rozróżnienia opartego na przeciwstawieniu fikcji i rzeczywistości - przyniosły prawdziwy przełom w rozpatrywaniu bardziej twórczego dziennikarstwa w kategoriach literatury.

Od początku swego istnienia piśmiennictwo hiszpańskie w sposób niezwykle płodny eksploatowało związki między rzeczywistością a zmyśleniem, faktem i wyobraźnią. Dzięki badaniom filologa Ramóna Menéndeza Pidala wiemy na przykład, że pierwsze hiszpańskie kroniki historyczne wykorzystywały poematy epickie w charakterze źródeł informacji. Pod koniec XIX wieku wspomniany badacz zrekonstruował na podstawie kronik obszerne fragmenty zaginionego tekstu Cantar de los siete infantes de Lara, powstałego około roku 1000. Zarówno poematy epickie, jak i pieśni romance miały za zadanie rozpowszechniać informacje na temat mniej czy bardziej bieżących zdarzeń (stąd można mówić, że utwory te należą do dalekich przodków dziennikarstwa ${ }^{51}$ ), zaś wędrowny poeta (juglar, trovador) swobodnie mieszał rzeczywistość ze zmyśleniem, w zależności od oczekiwań słuchaczy. Warto też przypomnieć, że pamięć o banicie Rodrigu Ruy Díazie, w rzeczywistości nie zawsze oddanym kastylijskim interesom, przetrwała w postaci, w jakiej ukształtował ją średniowieczny poemat Cantar de mío Cid. Jeśli więc - wbrew historycznym źródłom - pamiętamy o Cydzie jako o niezłomnym herosie

${ }^{47}$ El periodismo. Teoría y práctica, ed. N. González Ruiz, Barcelona 1953, s. 130.

${ }^{48}$ G. Martín Vivaldi, Géneros periodísticos: Reportaje, crónica, artículo (Análisis diferencial), Madrid 1973, s. 201. s. 123.

49 J.L. Martínez Albertos, La noticia y los comunicadores públicos, Madrid 1978,

${ }^{50}$ S. Bernal, L.A. Chillón, Periodismo informativo de creación, Barcelona 1985; L.A. Chillón, La palabra facticia. Literatura, periodismo y comunicación, Valencia 2014 (pierwsze wydanie 1999).

${ }_{51}$ J. Acosta Montoro, Periodismo y literatura, t. I, Madrid 1973, s. 148. 
bez skazy, to dzięki przekazowi literackiemu ${ }^{52}$. Przekraczanie granic między fikcją a rzeczywistością i systematyczna obecność metalepsji stały się wyznacznikami kultury hiszpańskiej, czego najbardziej wyrazistym owocem jest Cervantesowski Don Kichote. W tym kontekście nie dziwi zupełnie, że świat hiszpańskiego dziennikarstwa, u swego zarania, genetycznie związany jest ze światem literatury.

Przyglądając się hiszpańskiemu dziennikarstwu XVIII wieku, czyli temu, co krytyka nazywa „prehistorią” tej dziedziny, zauważamy, że pierwsze pisma nie tylko chętnie drukowały teksty literackie czy ich recenzje, ale nade wszystko pierwsi dziennikarze byli literatami. Prasa szybko stała się w Hiszpanii jednym z kanałów dystrybucji literatury, co widać już od czasów istnienia „Diario de los literatos” (1737). Ubogie w informacje periodyki chętnie oferowały swym czytelnikom nie tylko teksty literackie autorów współczesnych, ale również drukowały klasyków, takich jak Jorge Manrique, Fray Luis de León czy Luis de Góngora oraz zamieszczały tłumaczenia z obcych języków. Pamiętajmy również, że przesiąknięte duchem oświecenia Cartas marruecas (Listy marokańskie) José Cadalsa zostały poddane cenzurze i nie ukazały się za życia autora, mimo że były w obiegu w postaci odpisów, komentowanych na literackich spotkaniach towarzyskich (tertulias). Teksty te częściowo ukazały się w latach 1788-1799 na łamach „Correo de Madrid”. We Wstępie do tej powieści epistolarnej, częściowo wzorowanej na Listach perskich Monteskiusza, Cadalso w następujący sposób odnosi się do zawartej w niej krytyki społeczeństwa:

Tego typu krytyki cieszą się tak dużym powodzeniem dzięki formie epistolarnej, która sprawia, że ich lektura staje się wygodna, ułatwia ich rozpowszechnianie oraz czyni styl przyjemnym w odbiorze. Forma ta zawdzięcza swój sukces również rzekomym autorom i ich obcemu pochodzeniu, gdyż ci, choć ogólnie nie mówią nowych rzeczy, wypowiadają je z pewnego rodzaju świeżością, która się podoba ${ }^{53}$.

Gatunek epistolarny sprawia, iż tekst staje się przyjemny w odbiorze, co bez wątpienia ułatwi jego późniejszą dystrybucję w odcinkach na stronach wspomnianej gazety. Zwróćmy również uwagę, że nieuniknione krytyczne spojrzenie

52 O tym, że to literatura zapewnia nieśmiertelność, zdaje się pamiętać znakomity znawca literatury hiszpańskiej Francisco Rico, który w Czarnych plecach czasu Javiera Maríasa prosi autora, aby ten umieścił go koniecznie w charakterze bohatera w jednej ze swych powieści. Choć, biorąc pod uwagę niejasny, chwiejny status wspomnianego tekstu, trudno mówić o „rzeczywistym” Franciscu Rico w którejkolwiek z książek Maríasa, faktem jest, że w Los enamoramientos (2011) i w Así empieza lo malo (2014) krytyk przeistacza się w postać literacką.

53 J. Cadalso, Introducción [w:] idem, Cartas marruecas, ed. S. Fortuño Llorens, Barcelona 2000, s. 51. Tłumaczenia cytatów, jeśli nie wskazano inaczej, pochodzą od autorki. 
na społeczeństwo hiszpańskie idzie $\mathrm{w}$ parze $\mathrm{z}$ pewnymi strategiami typowymi dla utworu fikcyjnego (jak zabieg znalezionego rękopisu), stąd powołanie na Cervantesa w cytowanym Wstępie. Wszystkie elementy, które wspólistnieją w Cartas marruecas - krytyka społeczeństwa, zabiegi fikcyjne, funkcjonowanie w warunkach cenzury, publikacja prasowa - pozwalają nam spójnie przejść do kolejnego etapu rozwoju hiszpańkiej prasy oraz, na bardziej ogólnym poziomie, zrozumieć historyczne uwarunkowania bardzo mocno obecnej funkcji etycznej w dziennikarstwie i literaturze Hiszpanii.

Rodzący się kapitalizm XIX wieku spowodował rozkwit czasopiśmiennictwa korzystającego $\mathrm{z}$ unowocześnionych technologii druku ${ }^{54}$. Periodyki stały się częścią rynku, rywalizując między sobą w walce o czytelnika i fakt ten bezspornie determinował rodzaj języka, jakim dziennikarz operował. Pisarz-dziennikarz nie zawsze bowiem był właścicielem słowa, którym się posługiwal ${ }^{55}$. Aby uzmysłowić sobie sieć zależności, jakim było poddane pisarstwo w prasie, należy wziąć również pod uwagę fakt, że dziennikarstwo stanowiło dla swych adeptów trampolinę do kariery literackiej bądź politycznej ${ }^{56}$. Okoliczności te (a dodajmy jeszcze zmiany polityczno-społeczne zapowiadające pewną liberalizację rządów oraz - po krótkim okresie oddechu - coraz bardziej restrykcyjne działanie cenzury) stanowią tło dla twórczości Mariano José de Larry (1809-1837), będącej istotnym etapem zacieśnienia związków między literaturą a dziennikarstwem. Autor ten stał się ofiarą pewnego paradoksu: z jednej strony w swych satyrycznych artykułach, pisanych pod pseudonimami, piętnował przestarzałe i bezpłodne formy życia społecznego, typowe dla ancien régime, z drugiej zaś dostrzegał ograniczenia i pustkę nowoczesności, rozumianej jako rozwój przemysłu, nauki, kolei, czyli postęp o charakterze materialnym ${ }^{57}$. Pod tym względem ciekawy wydaje się następujący fragment, w którym Larra odnosił się do zmian, jakie w jego czasach dotknęły literaturę i dziennikarstwo: „Fakty zastąpily idee. Gazety - książki. Pośpiech i szybkość stały się duszą naszego życia, a to, czego nie robi się pośpiesznie w XIX wieku, nie robi się wcale" ${ }^{88}$. Postęp sprawil, że przestrzeń uległa skurcze-

54 B. Baczyńska, Historia literatury hiszpańskiej, Warszawa 2014, s. 302.

55 Á. Estévez Molinero, Relaciones entre literatura y periodismo: implicaciones históricas (y en páginas interiores, Larra, Galdós y Umbral), „Epos” 1998, vol. 14, s. 257.

56 Zob. M. Ramos Corrada, Periodismo y literatura en el XIX. El semanario „El Arte”, „Epos” 2000, vol. 16, s. 197-209. Z analizy tygodnika „El Arte” wynika, że żaden ze współpracowników pisma nie parał się wyłącznie dziennikarstwem, większość wykonywała wolne zawody bądź zajmowała się literaturą lub/i polityką.

$57 \mathrm{Z}$ tej perspektywy przedstawiciele neoromantycznego modernizmu hiszpańskiego (mam na myśli szeroką wizję modernizmu, z włączeniem postawy Pokolenia '98) należy uznać za spadkopierców intelektualnej spuścizny Larry.

58 M.J. de Larra, Un periódico nuevo, „La Revista Española”, 460, 1835; http: / /www. cervantesvirtual.com/obra-visor/un-periodico-nuevo--0/html/ff7a2e42-82b1-11 df -acc7-002185ce6064_1.html [dostęp: 15.10.2015]. 
niu i pośpiech zawładnął ludzkim umysłem. Czas wielkich książek i idei dobiegł końca, zaś dominacja faktu nad myślą, a co za tym idzie, dziennikarstwa nad literaturą, stała się - w rozumieniu Larry - wyróżnikiem jego czasów. Recenzując w 1836 roku na łamach „El Español” artykuły Mesonera Romanosa, Larra zauważa również skutki, jakie nowe czasy przyniosły dla stylu pisarza związanego z publikacjami prasowymi. Lekkość stylu musi tu iść w parze z głębią obserwacji, precyzja łączy się z wdziękiem, a wszystko to nie zapominając o szerokiej publiczności, o której względy zabiega pisarz-dziennikarz ${ }^{59}$. Wspomnianej stylistycznej precyzji towarzyszy swoista ekonomia języka, którą autor winien sobie narzucić, aby nie popaść w pułapkę stylu nazbyt dosłownego i trywialnego.

Uwagi Larry bywały przygnębiające. Szczególnie smutne refleksje towarzyszyły mu, kiedy zestawiał atmosferę intelektualną Madrytu z wolnością i bogactwem artystycznej wypowiedzi Paryża. Gdy pod koniec życia, w 1836 roku, pisał swoje słynne zdanie „Pisać w Madrycie to płakać” („Escribir en Madrid es 1lorar" ${ }^{00}$ ) nie nawiązywał, jak niekiedy interpretowano, do kłopotów finansowych (dziś wiemy, że w tamtym czasie był najlepiej opłacanym hiszpańskim dziennikarzem), lecz do peryferyjnego charakteru literatury hiszpańskiej i do warunków cenzury, w jakich przyszło mu funkcjonować. Przypomnijmy w tym miejscu, że „El Duende satírico”, w którym ukazały się jego pierwsze satyryczne artykuły w 1828 roku, został zawieszony przez rząd rok później, taki sam los spotkał gazetę „El Pobrecito hablador”, zamkniętą w 1833 roku.

W ten sposób, pod czujnym okiem cenzury i przy aktywnym udziale Larry, narodziły się w hiszpańskiej prozie pierwszej połowy XIX wieku nowe gatunki, należące do tzw. prozy rodzajowej (el costumbrismo), genetycznie związanej z nośnikiem prasowym. Literatura ta przybierała rozmaite formy: cuadros (escenas) de costumbres (obrazki obyczajowe), fisiologías (szkice fizjologiczne) czy tipos (typy $)^{61}$. Co ciekawe, współcześnie uważa się, że proza ta dała początek rozwojowi

59 M.J. de Larra, „Panorama Matritense”: Cuadros de costumbres de la capital observados y descritos por un Curioso Parlante. Artículo segundo y último, „El Español. Diario de las Doctrinas y los Intereses Sociales", 233, 1836, http://www.biblioteca.org.ar/ libros/70042.pdf [dostęp: 15.10.2015].

60 M.J. de Larra, Horas de invierno, „El Español. Diario de las Doctrinas y los Intereses Sociales", 420, 1836, 233, 1836; http://www.cervantesvirtual.com/obra-visor-din/ horas-de-invierno--0/html/ff84291a-82b1-11df-acc7-002185ce6064_2.html\#I_0 [dostęp: 21.10.2015].

${ }_{61}$ B. Baczyńska, Historia literatury... , s. 302. Dominowały obrazy z życia miejskiego, ponieważ to klasa średnia stanowiła główną grupę odbiorców tego typu literatury. Oprócz Larry, do kostumbrystów należy zaliczyć Ramóna Mesonera Romanosa i Serafína Estebáneza Calderóna. Wszyscy pisali pod pseudonimami. Cuadros z życia stolicy Mesonera Romanosa, opublikowane na łamach „La Revista Española” w latach 1832-1833, wydane zostały kilka lat później w trzech tomach pod tytułem Panorama matritense. 
reportażu ${ }^{62}$. Jak widać, trudno dziś przecenić rolę Larry w wykrystalizowaniu się świadomości zmian, jakie przyniósł z sobą XIX wiek w przestrzeni kultury, szczególnie $\mathrm{z}$ rozpatrywanej przeze mnie perspektywy związków między literaturą a dziennikarstwem.

Warto uzmysłowić sobie, że pomimo dokuczliwej cenzury, uwarunkowania społeczne, polityczne i kulturowe, jakim poddana jest twórczość dziennikarska Larry, doprowadziły do narodzin hiszpańskiej powieści realistycznej, której geneza nieprzypadkowo zbiegła się z intensywnym rozwojem dziennikarstwa ${ }^{63}$. Larra, podobnie jak wcześniej Cadalso, kierował bowiem swe krytyczne spojrzenie na czasy mu współczesne z nadzieją na możliwość kształtowania postaw obywatelskich i społecznych, a prasę traktował jako medium, które miało mu pozwolić osiagnąć ten szczytny cel. Pisarz stał się swego rodzaju reporterem, rejestrującym zjawiska społeczne wymagające naprawy, a tzw. powieść realistyczna narodziła się jako fikcyjna transpozycja obserwacji rzeczywistości. Mariaż literatury z dziennikarstwem uczynił ze społeczeństwa materię powieści (materia novelable), jak to ujął w tytule swego przemówienia skierowanego do członków Królewskiej Akademii Hiszpańskiej w 1897 roku Benito Pérez Galdós (1843-1920), dziennikarz, powieściopisarz i dramaturg. W mowie tej czytamy o pragnieniu uchwycenia wszystkich przejawów życia: „Powieść jest obrazem życia, a sztuka powieści polega na odtwarzaniu ludzkich charakterów, namiętności, słabości, tego, co małe i co wielkie, dusz i fizjonomii, wszystkiego, co duchowe i fizyczne, co nas konstytuuje i nas otacza" ${ }^{64}$.

Powieści Péreza Galdósa pozwalają zrekonstruować mapę Madrytu z drugiej połowy XIX wieku. Jego artykuły prasowe, choć z różnej perspektywy, podejmują tematy, które znajdują swoje odbicie w twórczości powieściowej, jak choćby motyw świąt Bożego Narodzenia czy święto San Isidro, o których mowa w La desheredada $(1881)^{65}$. Świadom potęgi prasy hiszpańskiej swoich czasów, autor pisywał do licznych periodyków (dziś nie wiemy nawet do ilu, krytycy mówią, że od dwudziestu kilku do czterdziestu), aby wybadać reakcję swoich czytelników (tych wyspecjalizowanych - innych pisarzy - i zwykłych czytelników reprezentujących zazwyczaj klasę średnią). Według znawców jego twórczości dotyczy to na przykład krótkiej powieści Torquemada en la hoguera, opublikowanej w dwóch odcinakch w „La España Moderna” w 1889 roku. Sugestie i opinie Emilii Pardo Bazán, José Maríi de Peredy i Narcísa Ollera zachęciły Galdósa do dalszej pracy

62 M. Cruz Seoane, Historia del periodismo en España, t. II, Madrid 1983, s. 133.

63 Zob. A. Chillón, La palabra facticia..., s. 155-183.

64 B. Pérez Galdós, La sociedad presente como materia novelable, http://www.biblioteca.org.ar/libros/130020.pdf [dostęp: 12.10.2015].

65 Zob. M.L. Boo, Galdós: periodismo y novela (La desheredada, La incógnita y tres artículos de La Prensa de Bunos Aires, „Anales galdosianos” 1988, vol. 23, s. 123-131. 
nad swoim bohaterem, której efektem były trzy inne powieści poświęcone madryckiemu lichwiarzowi Torquemadzie ${ }^{66}$. Tak więc Galdós traktował swoje publikacje w prasie jako rodzaj eksperymentu, który mógł przeprowadzić dzięki komunikacji, jaką gwarantowała mu działalność dziennikarska. Dodajmy również, że autor ten pisywał do periodyków latynoamerykańskich, a współpraca między pisarzami z Hiszpanii i Ameryki Południowej na łamach prasy ulegnie znacznemu pogłębieniu w okresie modernizmu.

Publikacje prasowe Galdósa miały charakter zarówno publicystyczny jak i fikcyjny. Te ostatnie, jak było w zwyczaju, ukazywały się w odcinkach (por entregas), a dopiero potem $\mathrm{w}$ formie książek. Taki rodzaj publikacji nieuchronnie pociągał za soba pewne stylistyczne i strukturalne konsekwencje, czytelnika należało bowiem zachęcić do zakupu kolejnego numeru periodyku, odpowiednio dozując napięcie. W odcinkach na łamach „La Ilustración de Madrid” w 1871 roku ukazał się na przykład zadziwiający tekst La novela en el tranvía (Powieść w tramwaju), bedący dowodem na to, że Galdós już u progu swojej kariery powieściopisarskiej był świadom ograniczeń związanych z przypisywaną literaturze realistycznej funkcją mimetyczną. Wbrew wrażeniu, jakie możemy odnieść, czytając cytowany wcześniej tekst La sociedad presente como materia novelable, Galdós ujawnia złożoność procesu twórczego oraz dyskursywny charakter tekstu będącego jego owocem ${ }^{67}$. La novela en el tranvía ukazuje bowiem bohatera-narratora, który jadąc tramwajem, wy ob raża sobie historię (powieść), korzystając z bogactwa źródel, jakie roztacza przed nim podróż przez Madryt i różnorodność typów ludzkich, z jakimi się styka. Impulsem do snutej mentalnie opowieści jest spotkanie bohatera ze znajomym lekarzem, który wprowadza motyw hrabiny i jej męża. Ponieważ jednak podróż lekarza dobiega końca i nie zdąża on zdradzić dalszego ciągu swej intrygującej historii, bohater poszukuje innych źródeł informacji na temat nieszczęść hrabiny i znajduje je przypadkiem na skrawkach gazety, w którą opakował wiezione przez siebie książki. Inspiracją do rozwinięcia perypetii hrabiny i hrabiego będą też towarzysze podróży bohatera, ich fizjonomie oraz dialogi, jakie między sobą toczą. W wielu momentach opowiadania historia bohatera w tramwaju (pierwszy poziom fikcji) i historia właśnie two rzo na (drugi poziom fikcji) płynnie nakładają się na siebie, sugerując, z jednej strony, umowność granicy między fikcją a rzeczywistością oraz, z drugiej strony, nieobiektywny charakter procesu twórczego (jego duża część jest dziełem wy-

${ }^{66}$ Zob. R. Davies, Galdós y la prensa: hacia una revisión crítica de la mina inagotable, [w:] Actas del octavo congreso internacional de estudios galdosianos, Las Palmas 2005, s. 513.

${ }^{67}$ Zob. A.J. García Osuna, Novela en el tranvía: Galdós y la problematización del esquema discursivo del XIX, [w: ] Actas del noveno congreso internacional de estudios galdosianos, Las Palmas 2009, s. 288-293. 
obraźni, inspirowanej jedynie przez bodźce świata zewnętrznego oraz noszącej znamiona szaleństwa, przynajmniej w odbiorze innych podróżnych) ${ }^{68}$. Zauważmy więc, że związki między dziennikarstwem a literaturą w oczach Galdósa mają charakter złożony: po pierwsze prasa stanowi jedno ze źródeł inspiracji dla narratora, podobnie jak elementy rzeczywistości; po wtóre zaś to właśnie prasa jest dla pisarza odpowiednim kanałem komunikacji, za pomocą którego dzieli się z czytelnikiem refleksjami na temat nieoczywistego charakteru relacji między przedmiotem, myślą a słowem. Celem Galdósa było najprawdopodobniej ośmieszenie powieści typu folletín (literatura sentymentalna i sensacyjna, ukazująca się jako stały dodatek do czasopism). Podobnie jak stało się z Cervantesowskim Don Kichotem kilka wieków wcześniej, realizacja pierwotnego zamiaru (parodia innych tekstów) przyniosła problematyzację o charakterze metaliterackim.

Hiszpański modernizm przyniósł nadzwyczajny rozwój publikacji prasowych. Autorefleksyjność typowa dla literatury tego okresu znalazła bowiem swoje ujście $\mathrm{w}$ rozlicznych artykułach, esejach i kronikach publikowanych na łamach gazet, będących jednocześnie platformą dla refleksji natury społecznej i politycznej. Co nie bez znaczenia dla mojego tematu, na przełomie XIX i XX wieku - w związku z aferą Dreyfusa, a potem, jak prześledził Edward Inman Fox $^{69}$, z procesem i egzekucją Francisca Ferrery Guardii (1909) - w Hiszpanii wyłania się kategoria intelektualisty (un intelectual). Jest nim pisarz (lub ogólniej artysta), który zabiera głos w sprawach dotyczących kraju, w celu napiętnowania bolesnych zjawisk i wskazania dróg odnowy (regeneración). Paradygmatycznym przykładem intelektualisty pierwszych dziesięcioleci XX wieku jest Miguel de Unamuno (1864-1936), którego niezwykle bogata twórczość prasowa miała za zadanie budzić u czytelnika niepokój, zarówno natury egzystencjalnej, jak i moralnej oraz społecznej (nieprzypadkiem Unamuno zostal nazwany przez Ernsta Curtiusa excitador Hispaniae). W pisarstwie prasowym Unamuna bardzo często przewija się postać don Kichota, jako wcielenie hiszpańskości (Muera don Quijote, „Vida Nueva”, 1898), a z czasem jako model intelektualisty-herosa (pod wpływem Carlyle’a), który tchnie energię witalną w ogarnięty marazmem naród (jak widać w eseju - opublikowanym w formie książki - Vida de don Quijote y Sancho, 1905). Oryginalna osobowość Unamuna, niczym Sokrates obalający powszechne przekonania za pomocą paradoksu, nie pozostała bez wpływu dla stylu eseju. W istocie gatunek ten, przeżywający prawdziwy rozkwit w okresie modernizmu, wzbogacił się o formy typowe dla dialogu, Unamuno bowiem

68 B. Pérez Galdós, La novela en el tranvía, „La Ilustración de Madrid”, 46, 1871, http://www.biblioteca.org.ar/libros/130023.pdf [dostęp: 1.12.2015].

69 E. Inman Fox, El año 1898 y el origen de los intelectuales, [w: ] J.L. Abellán et al., La crisis de fin de siglo: ideología y literatura. Estudios en memoria de R. Pérez de la Dehesa, Barcelona 1974, s. 17-24. 
w sposób systematyczny wprowadzał do swych rozważań zmyślonego lub realnego rozmówcę, tworząc w ten sposób formę monodialogu (monodiálogo). Ponadto, będąc zwolennikiem kulturowej wspólnoty krajów hiszpańskojęzycznych (hispanidad) w obliczu zagrożenia płynącego ze świata anglosaskiego, Unamuno prowadził bardzo szeroko zakrojoną działalność publicystyczną skierowaną do czytelnika hispanoamerykańskiego, pisząc do gazet takich, jak „La Nación” w Buenos Aires czy „El Cojo Ilustrado” w Caracas lub „El Siglo” w Montevideo.

Na przełomie XIX i XX wieku spektakularny rozwój przeżywały relacje z podróży, którymi autorzy dzielili się ze swymi czytelnikami na łamach prasy. Sukces, jakim cieszył się hiszpański pejzaż, należy wiązać w znacznej mierze z wkładem

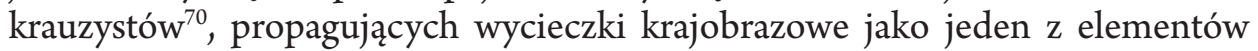
wykształcenia. Krauzyści uważali bowiem, że Hiszpania to nie tylko problem polityczny czy moralny, lecz przede wszystkim geograficzna obecność, którą należy spenetrować. To odkrywanie geograficznej rzeczywistości miało również inny podtekst: poszukiwanie tożsamości, mocno obecne w eseistycznej twórczości tamtych lat, rozumiane było jako zbliżenie do ludzi prostych, ich tradycji i codziennych rytuałów, które w obliczu kryzysu instytucji i elit politycznych mogły wnosić zbawcze wartości w życie kraju. Przykładem tego typu twórczości są teksty wydane w 1922 roku przez Unamuna w tomie Andanzas y visiones españolas, publikowane uprzednio w latach 1911-1922 na łamach hiszpańskiej prasy. Poza swą bezsporną wartością autobiograficzną, artykuły te stanowią bezcenny zapis wrażliwości i estetyki symbolistycznej ${ }^{71}$.

Dla modernizmu hiszpańskojęzycznego bardzo szczególną formą ekspresji prasowej jest kronika. Jej nadzwyczajny rozwój w tamtym okresie jest dowodem na poszukiwanie drogi kompromisu między koniecznością utrzymywania się z pisarstwa a estetycznymi ambicjami modernistów. $\mathrm{Z}$ jednej strony bowiem publikowanie kronik, z definicji silnie osadzonych w świecie aktualnym, w toku bieżących spraw, było źródłem zarobku (zresztą zarobku dość miernego w Hiszpanii, za to w Ameryce Południowej zupełnie przyzwoitego). Z drugiej zaś kronika dawała możliwość estetyzacji i subiektywizacji rzeczywistości, co pozwalało autorom zachować poczucie względnej niezależności wobec znienawidzonego filistra i praw rudymentarnego kapitalizmu. Przykładem modernistycznej kroniki może być La ruta de don Quijote José Martíneza Ruiza (Azorín, 1873-1967). Jest to zbiór artykułów, które pisarz zredagował w czasie swojej dwutygodniowej podróży po Kastylii śladami Cervantesowskiego bohatera w 1905 roku,

${ }^{70}$ Mam na myśli intelektualistów pozostających pod wpływem niemieckiego filozofa Karla Ch.F. Krausego (1781-1832), mających duży udział w edukacji poprzez Institución Libre de Enseñanza, instytucji założonej w 1876 roku.

${ }^{71}$ Zob. A. Kłosińska-Nachin, Miguel de Unamuno y el modernismo. Aproximación a la prosa unamuniana, Łódź 2012, s. 115-124. 
dla upamiętnienia dwusetnej rocznicy wydania pierwszego tomu powieści Cervantesa. Tekst to szczególnie istotny, gdyż zbiera kilka ważnych dla modernizmu wątków, takich jak refleksja nad hiszpańskością z odniesieniem do don Kichota, relacje z podróży w postaci kroniki oraz estetyzacja przestrzeni. Dodajmy, że kroniki Azorína ukazały się na łamach dziennika „El Imparcial”, którego dyrektor José Ortega Munilla, powierzając Azorínowi zadanie odwiedzenia najważniejszych miejsc związanych z don Kichotem, podarował mu mały pistolet, na wypadek gdyby podróżując po kastylijskich odludziach, stał się ofiarą agresji. Wiemy, że pistoletu Azorín nie użył, zaś podróż po Kastylii stała się swoistym ćwiczeniem wrażliwości, w którym do głosu doszły podstawowe elementy estetyki Azorína. Autor ten z jednej strony wypatrywał atawistycznych donkichotowskich gestów z perspektywy tzw. „problemu Hiszpanii”, z drugiej zaś bardzo uważnie wsłuchiwał się w reakcje swego ego, karmionego lekturą powieści Cervantesa ${ }^{72}$.

Po wojnie domowej prasa i literatura hiszpańska funkcjonowały w warunkach bardzo szczególnych. $\mathrm{O}$ tym, jak silne relacje łączą dwie interesujące mnie sfery, może świadczyć polemika, jaka wywiązała się na I Międzynarodowym Kongresie o Powieści w maju 1959 roku w Formentor, wokół formuły powieści realizmu krytycznego, reprezentowanej przez hiszpańskich powieściopisarzy z Juanem Goytisolo (1931) na czele, która zderzyła się z koncepcją powieści eksperymentalnej nouveau roman, której przedstawicielem był Alain Robbe-Grillet. Argumenty hiszpańskiej delegacji najlepiej zilustrują słowa Juana Goytisola: „[... [ powieść pełni w Hiszpanii funkcję dokumentalną, która we Francji i w pozostałych krajach Europy przypisywana jest prasie. Przyszły historyk społeczeństwa hiszpańskiego będzie musiał odwołać się do powieści, aby zrekonstruować życie codzienne kraju poprzez gęstą zasłonę dymu i niedomówień, typowych dla naszych gazet ${ }^{73}$ ". Jest bardzo znamienne, że $\mathrm{z}$ perspektywy hiszpańskiego powieściopisarza $\mathrm{z}$ końca lat pięćdziesiątych $\mathrm{XX}$ wieku misja powieści łączy się w sposób nieunikniony z wolnością (lub jej brakiem) prasy oraz z zobowiązaniami wobec społeczeństwa, jakie ciążą na obu tych dziedzinach ${ }^{74}$. W obliczu cenzury powieść, dysponując szerszym niż prasa wachlarzem narzędzi estetycznych, pełni zarazem funkcję informacyjną i kronikarską. W obydwu przypadkach jest to funkcja nierozerwalnie związana ze służbą społeczeństwu.

Nie oznacza to bynajmniej, że we frankistowskiej Hiszpanii pisarze zrezygnowali z dziennikarstwa. Współpraca $\mathrm{z}$ tą bardzo mocno kontrolowaną

72 J. Martínez Ruiz, La ruta de don Quijote, Madrid 1998.

73 J. Goytisolo, El furgón de cola, Barcelona 1976, s. 60.

74 Dodać należy, że Juan Goytisolo w latach sześćdziesiątych odszedł od formuły powieści społecznie zaangażowanej. Niemniej jednak uwikłanie intelektualisty w „problem Hiszpanii” stanowi jeden z punktów zapalnych trylogii Señas de identidad (1966), Reivindicación del conde don Julián (1970) i Juan sin tierra (1976). 
przez reżim sferą życia publicznego bywała szkołą pisarstwa dla wielu dysydentów, wśród których na pierwszym miejscu wymienić należy Miguela Delibesa (1920-2010), twórcę tzw. Grupo Norte. Autor ten wspólpracował od 1941 roku z dziennikiem „El Norte de Castilla”, początkowo jako karykaturzysta, następnie jako redaktor (od 1944 roku), aby stopniowo przejmować coraz więcej sekcji tematycznych, takich jak „Desde mi cabina” (poświęcona kinu), „Vistas al exterior” (jej tematem było dziennikarstwo zagraniczne) czy „Momento deportivo" (sekcja sportowa). Organ nadzorujący działalność prasy (Delegación Nacional de Prensa), oprócz sprawowania kontroli, niejednokrotnie narzucał gazetom tematy, które powinny znaleźć właściwe rozwinięcie na ich łamach. W ten sposób na przykład redaktorzy mieli obowiązek przekonywać obywateli o tym, że ich poziom życia (ceny żywności, zaopatrzenie) przewyższa te same wskaźniki w większości krajów europejskich ${ }^{75}$. Brak zapału w realizowaniu celów propagandowych sprawil, że Delibes szybko stał się dziennikarzem niewygodnym dla rządzących ${ }^{76}$. W 1960 roku przejął kierownictwo dziennika i sprawował tę funkcję przez sześć kolejnych lat, w czasie których w sposób mniej czy bardziej otwarty ścierał się z przedstawicielami władz. Delibes nadał kierowanemu przez siebie dziennikowi linię wyraźnie regionalną, występując w obronie podupadłej Kastylii i domagając się od rządu stosownych reform. W 1961 roku z jego inicjatywy powstał suplement „El Caballo de Troya” („Koń Trojański”), którego nazwa obrazuje krytyczny stosunek do władz oraz sposób działania, nastawiony na rozsadzenie systemu od środka. Aresztowanie Césara Alonsa de los Ríosa, dziennikarza tej sekcji, oraz nieustająca presja ze strony cenzorów (w szczególności Demetrio Ramosa o pseudonimie „Viejecita”, niestrudzenie gnębiącego Delibesa) doprowadziły do jego rezygnacji z kierowania dziennikiem. Ale to, czego Delibesowi nie udawało się przekazać na łamach prasy, znajdowało ujście w powieściach, jak chociażby w Las ratas (Szczury) z 1962 roku, ukazującej skrajną biedę i degradację kastylijskiej wsi. W istocie dziennikarstwo służyło mu jako rodzaj „radaru", za pomocą którego wychwytywał problemy rozwijane później na kartach

${ }^{75}$ Chodzi o polecenia, jakie Delegación Nacional de Prensa wydała w październiku 1943 roku; zob. D.F. Arranz, Miguel Delibes periodista y „El Norte de Castilla”: libertad de información frente a censura, „Crítica” 2010, vol. 968, s. 96-99.

${ }_{76}$ Co ciekawe, w czasach demokracji Delibes w dalszym ciągu pozostawał niewygodny, choć już w nieco innym sensie. Pisarze i intelektualiści przestali się nim interesować, gdyż był autorem nazbyt lokalnym, podczas gdy obowiązującym modelem był wówczas kosmopolityzm, a w szczególności otwarcie na kraje anglosaskie. W sposób przejmujący wyjaśnia to Antonio Muñoz Molina (idem, Delibes, a lo lejos, „El País”, 20.03.2010, http://elpais.com/diario/2010/03/20/babelia/1269047536_850215.html [dostęp: 17.12.2015]). 
powieści ${ }^{77}$. Obcowanie ze zwykłymi ludźmi i ich codziennymi problemami (czyli to, czemu poświęcał się jako dziennikarz) nauczyło Delibesa wrażliwości na sytuację słabszych oraz poszukiwania głębszych sensów w trywialności ${ }^{78}$, cech, które odnajdujemy w jego pisarstwie powieściowym. Ponadto precyzyjny i zwięzly styl typowy dla powieści Delibesa wypracowany został - jak sam autor przyznaje - właśnie dzięki działalności dziennikarskiej, od której rozpoczął swoją przygodę z pisarstwem. Ślady dziennikarstwa w twórczości literackiej Delibesa przybierają również bardziej bezpośrednią formę. W Mi idolatrado hijo Sisí (Mój uwielbiany syn Sisí, 1953) informacje z gazety (konkretnie „El Norte de Castilla”) otwierają kolejne rozdziały, wyznaczając strukturę tekstu powieściowego. I wreszcie ostatnia rzecz, którą powieści Delibesa zawdzięczają dziennikarskiemu zaangażowaniu autora: głosy, tak dobrze słyszalne i charakterystyczne w jego tekstach - głównie dzięki dialektyzmom i potoczności - to głosy, w które wsłuchiwał się, pisząc do „El Norte de Castilla", gdy przeprowadzał wywiady z lokalnymi osobistościami ${ }^{79}$.

Demokratyczna transformacja w Hiszpanii pociągnęła za sobą gwałtowny rozwój felietonu (columna), widoczny szczególnie od lat dziewięćdziesiątych ubiegłego stulecia. Napływ pisarzy do gazet, niejednokrotnie kojarzonych z odmienną linią ideologiczną od tej, jaką reprezentował dany periodyk, miał przyciągnąć nowych czytelników, przekonując ich o otwartości gazety ${ }^{80}$. Jednocześnie zauważamy pewną podejrzliwość w stosunku do fikcji, w szczególności w odniesieniu do tematu wojny domowej, bardzo mocno obecnego w powieści hiszpańskiej ostatnich dekad. Zacieśnienie tradycyjnie bliskich przecież związków literatury z dziennikarstwem (trudno wskazać współczesnego pisarza hiszpańskiego, który nie pisałby do gazet) w połączeniu z wspomnianą niechęcią do zmyślania w sztuce zaowocowało rozkwitem estetyki non-fiction. W tym kontekście chciałabym zwrócić uwagę na refleksję dotyczącą roli i natury literatury, jaka stosunkowo często pojawia się w prasie codziennej w felietonach takich powieściopisarzy, jak Juan José Millás (ur. 1946) czy Javier Cercas (ur. 1962). Pierwszy tekst, jaki warto przytoczyć, nosi tytul Escribir (Pisać, 2000) i należy do hybrydowego gatunku articuento, łączącego cechy atykułu

77 Zob. J.F. Sánchez Sánchez, Delibes: querido escritor incómodo, „Revista Cálamo FASPE” 2010, vol. 56, s. 51-52.

${ }^{78}$ J.F. Sánchez Sánchez, El novelista como trasunto del periodista, [w:] Miguel Delibes. Nuevas lecturas críticas de su obra, ed. M. Pilar Celma Valero, M.J. Rodríguez Sánchez de León, Salamanca 2013, s. 116.

79 D. Villanueva, Seis claves para Miguel Delibes, „El Cultural”, 15.03.2010, http:// www.elcultural.com/noticias/letras/Seis-claves-para-Delibes/308 [dostęp: 12.11.2015].

${ }_{80}$ M.R. Marín Malavé, El columnismo de Juan José Millás en relación con su narrativa. Análisis de sus columnas en el País (1990-2018), Málaga 2011, s. 48-50. 
prasowego (artículo) i opowiadania (cuento), wymyślonego przez Juana José Millása. Pisarz ten regularnie współpracuje jako felietonista z dziennikiem „El País”. Wspomniany tekst został zainspirowany zatonięciem rosyjskiego okrętu Kursk na Morzu Barentsa latem 2000 roku, a konkretnie krótką notatką, znalezioną w kieszeni jednego z oficerów. Jej tekst brzmi: „13.15. Cała załoga 6, 7 i 8 przedziału przeszła do 9. Jest nas 23 osoby. Podjęliśmy taką decyzję po katastrofie. Nikt nie może wyjść na górę. Piszę po omacku"81. Juan José Millás nie kryje fascynacji tym tekstem, uznając, iż przynosi on odpowiedź na odwieczne pytanie dotyczące misji literatury: „Ciekawe jest to, że notatka z czterema linijkami znaleziona $w$ kieszeni martwego oficera nagle odpowiada na stare pytanie dotyczące roli literatury. Literatura służy do tego, żeby opowiadać. Wszyscy, którzy chcą pisać, powinni recytować tekst z Kurska jak modlitwę" ${ }^{82}$. W rozumieniu Millása literaturą staje się tekst wzięty z rzeczywistości, a nie tylko ją naśladujący, jak ma to miejsce $\mathrm{w}$ przypadku tzw. mimetyzmu formalnego, o którym niegdyś pisał Michał Głowiński w odniesieniu na przykład do formy epistolarnej czy dziennika ${ }^{83}$. Tych kilka zdań skreślonych w pośpiechu, których autor świadom jest rychłej śmierci, nieoczekiwanie aktualizuje mit Szeherezady z tym tylko, że jego opowieść nie ma mocy ocalającej od śmierci. Słowo bowiem przed niczym nie chroni, przeciwnie, jest świadectwem nieuchronnego. Okoliczności powstania notatki sprawiają, że pomimo swej nadzwyczajnej oszczędności środków językowych (ogranicza się ona do kilku niezbędnych, najczęściej numerycznych informacji) wywołuje ogromny ładunek emocji u czytelnika, uruchamiając mechanizm wyobraźni rekonstruującej scenę jej sporządzenia. Jednocześnie, co niezwykle znaczące, hiszpański pisarz, utożsamiając autentyczne pisarstwo $\mathrm{z}$ notatką anonimowego oficera, przypisuje sobie, zapewne w metaforycznym i egzystencjalnym sensie, jego kondycję za pomocą formuly: „Piszę po omacku”.

Bardzo podobną postawę reprezentuje Javier Cercas w tekście ze stycznia 2015 roku. Opublikowany w „El País Semanal” artykuł nosi tytuł Literatura más allá de la literatura (Literatura poza granicą literatury) i rozpoczyna się od zdania: „Jeden z najlepszych tekstów literackich, jakie w życiu czytałem, nie jest tekstem literackim" ${ }^{84}$. Następnie czytelnik dowiaduje się, że entuzjazm i podziw Cercasa

81 Cyt. za: Notatki $z$ „Kurska”, http://www.rmf24.pl/fakty/news-notatki-z-kurska,nId,204864 [dostęp: 12.11.2015].

82 J.J. Millás, Escribir, „El País”, 3.11.2000. http://elpais.com/diario/2000/11/03/ ultima/973206002_850215.html [dostęp: 3.11.2015].

${ }^{83}$ M. Głowiński, Powieść młodopolska. Studium z poetyki historycznej, Wrocław 1968, s. 192; zob. również idem, Gry powieściowe. Szkice z teorii i historii form narracyjnych, Warszawa 1973.

84 J. Cercas, Literatura más allá de la literatura, „El País”, 4.01.2015, http://elpais. com/elpais/2015/01/02/eps/1420212864_912263.html [dostęp: 17.09.2015]. 
wywołał list, jaki izreaelski pisarz David Grossman napisał do swego syna Uri, który zginął w czasie wojny na południu Libanu, zabity przez pocisk przeciwpancerny. W pierwszej wersji tekst ten był przemówieniem, jakie Grossman wygłosił na pogrzebie Uri. Widząc, że dziennikarze odtworzyli tekst, Grossman, aby uniknąć stylistycznych i merytorycznych niezręczności, przesłał go do redakcji gazet. Artykuł Grossmana został między innymi opublikowany przez „El País”. Dla Cercasa jest to tekst „nieskończenie bardziej literacki niż nieskończona liczba innych tekstów literackich" ${ }^{86}$, a literackość ta wynika, w pierwszej kolejności, z przekraczania granic literackości (czyli, precyzyjnie rzecz ujmując, jego literackość jest paradoksalnie pochodną charakteru non-fiction). Drugi wyznacznik literackości wynika, podobnie jak w interpretacji Millása, z ekstremalnych (tj. skrajnie przejmujących) okoliczności powstania tekstu: „Literatura jest tym, co jest pisane, jak gdyby autor za chwilę miał być poddany egzekucji. Lub jak gdyby właśnie został stracony, tak jak pisze Grossman. Wielka literatura to właśnie to, co jest na granicy literatury. Lub trochę poza tą granicą" ${ }^{87}$.

Na przykładzie tekstu i Millása, i Cercasa obserwujemy zmieniony kontekst dla funkcjonowania literatury. Stała się nim komunikacja społeczna, główny wyznacznik dziennikarstwa. W konsekwencji sztuka rozumiana jako z o b o wi ą za nie estetyczne została zastąpiona przez przekaz z dominantą o charakterze zobowiązania emocjonalnego, co doskonale rejestruje $\mathrm{i}$ - nade wszystko - eksploatuje Juan José Millás i Javier Cercas w cytowanych tekstach ${ }^{88}$.

Fascynacja rzeczywistością doprowadziła Javiera Cercasa do literatury non -fiction. Choć już w głośnej powieści Soldados de Salamina definiuje kategorię relato real, dopiero El Impostor (Oszust) z 2014 roku przyniósł pełną realizację ideału literatury bez fikcji. Tematem ostatniej powieści Cercasa jest historia kłamstwa Enrica Marco, który przez długie lata utrzymywal, że był więźniem obozu koncentracyjnego w Flossenbürg i kolejnym pokoleniom młodych Hiszpanów opowiadał o swoich dramatycznych doświadczeniach więziennych w rozlicznych wywiadach, pogadankach i wykładach. Przemawiał również w hiszpańskim parlamencie, doprawadzając do lez niejednego deputowanego. W 2005 Benito Bermejo Sánchez, skromny historyk wykazal, że opowieści Enrica Marco są na tyle niespójne, iż nie mogą być prawdą. Powieść Javiera Cercasa rejestruje wywiady, jakie

85 D. Grossman, Nuestra familia ha perdido la guerra, „El País”, 21.08.2006, http://elpais.com/diario/2006/08/21/opinion/1156111205_850215.html [dostęp: 11.01.2016].

${ }^{86} \mathrm{~J}$. Cercas, Literatura más allá...

87 Ibidem.

${ }^{88}$ Por. M. Hopfinger, Wspótczesne przemiany literatury a dziennikarstwo, [w:] Dziennikarstwo a literatura w XX i XXI wieku, red. K. Wolny-Zmorzyński, W. Furman, J. Snopek, Warszawa 2011, s. 13-23. 
pisarz przeprowadził ze swym bohaterem, a następnie krok po kroku w oparciu o dokumenty historyczne, archiwa i opinie ekspertów demaskuje kłamstwa lub, tam gdzie to możliwe, rekonstruuje prawdę. Podobnie jak w przypadku Soldados de Salamina, El impostor staje się jednocześnie zapisem procesu pisania, historia postaci skłania zaś Cercasa do zadawania pytań dotyczących kondycji pisarza. Wymyślanie historii, ze wszystkimi konsekwencjami tego procesu, w celu zaskarbienia sobie sympatii publiczności jest bowiem, w rozumieniu Cercasa, punktem stycznym między postacią Enrica Marco a zajęciem powieściopisarza: „Podobnie jak Marco, powieściopisarz wymyśla sobie życie fikcyjne, życie hipotetyczne, aby ukryć swoje prawdziwe życie i żyć innym, aby przetworzyć rzeczy wstydliwe i okropne oraz wszelkie niedostatki rzeczywistości, zamieniając je w fikcję, aby ukryć je przed sobą i przed innymi" 89 .

Autor El impostor stawia sobie za cel, między innymi, pogodzenie swojego bohatera $\mathrm{z}$ rzeczywistością ( $\mathrm{w}$ ten sam sposób, w jaki don Kichot uznaje swoje szaleństwo pod koniec drugiej części dzieła Cervantesa) i choć, jak wykazują publiczne reakcje Marco, celu tego nie osiągnąl, jego powieść zdaje się spełniać inną, bardziej ogólną misję, ściśle związaną z jej charakterem niefikcyjnym. Odchodząc od demiurgicznej roli literatury i opowiadając się za komunikacją za pomocą tekstu literackiego, Javier Cercas podejmuje bowiem istotne dylematy tożsamościowe Hiszpanów, stawiając zasadnicze pytania, dotyczące hiszpańskiej transformacji po śmierci generała Franco w 1975 roku. Niewygodna teza pisarza brzmi, że w tym trudnym historycznym momencie wielu Hiszpanów wymyśliło sobie na nowo przeszłość, przypisując sobie antyfrankistowską lub wręcz heroiczną postawę, podobnie jak to uczynił bohater El impostor ${ }^{90}$.

Trudno przecenić zasięg twórczej inspiracji, jaką stanowią dla siebie dziennikarstwo i literatura w Hiszpanii. Tradycyjnie silnie obecna funkcja etyczna w odniesieniu do artysty-intelektualisty hiszpańskiego po części tłumaczy tę więź, choć nie sposób dociec, czy funkcja ta jest przyczyną, czy raczej skutkiem tej relacji. Realizm, powieść non-fiction, esej, kronika i felieton są najbardziej dorodnymi owocami opisywanej więzi. W obliczu rosnącej ekonomizacji i cyfryzacji życia pisarz broni swej pozycji w społeczeństwie, próbując włączyć swą twórczość

${ }^{89} \mathrm{~J}$. Cercas, El impostor, Barcelona 2014.

$90 \mathrm{Na}$ przeciwległym biegunie $\mathrm{w}$ stosunku do literatury non-fiction znajduje się dziennikarstwo otwarcie posługujące się fikcją. Przykładem może być fikcyjny film dokumentalny (documental ficticio) Operación Palace, zrealizowany w 2014 roku przez dziennikarza Jordi Évole (ur. 1974), przedstawiający zamach stanu z 23 lutego 1981 roku w hiszpańskich Kortezach jako film wyreżyserowany przez José Luisa Garci. Dokument zwraca uwagę na ogromne możliwości manipulacji materiałem historycznym oraz na brak transparentności państwa w dochodzeniu do prawdy w odniesieniu do najnowszej historii Hiszpanii. Jak widać, zarówno literatura bez fikcji, jak i dziennikarstwo fikcyjne stawiają istotne pytania dotyczące współczesnego społeczeństwa hiszpańskiego. 
w główne nurty komunikacji społecznej, co wyjaśnia zacieśnienie opisywanych związków w ostatnich dziesięcioleciach. Bez wątpienia zjawisko to niesie z sobą szereg niebezpieczeństw. Przenikanie się literatury i mediów zachęca bowiem do poszukiwania czytelnika masowego, będącego niejednokrotnie amatorem reality show, czyli połączenia emocji z zapewnieniem (mniejsza o to, czy dotrzymywanym, czy nie) o p raw d zi w y m charakterze przeżywania. Publikacje prasowe dodatkowo wzmacniają pożądany efekt prawdziwości. Ale nie zapominajmy, że efektem kontaminacji literatury i dziennikarstwa jest też El impostor, powieść-dynamit ${ }^{91}$ wywołująca ważne debaty społeczne.

${ }_{91}$ Zob. wywiad z Javierem Cercasem z 10 grudnia 2014 roku, zrealizowany przez TV Española, Página 2: Javier Cercas sobre su novela El impostor, https://www.youtube. com/watch?v=IW2UTu7Y8Ac [dostęp: 11.01.2016]. 


\section{BIBLIOGRAFIA}

Acosta Montoro J., Periodismo y literatura, t. I-II, Madrid 1973.

Arranz D.F., Miguel Delibes periodista y „El Norte de Castilla”: libertad de información frente a censura, „Crítica” 2010, vol. 968, s. 96-99.

Baczyńska B., Historia literatury hiszpańskiej, Warszawa 2014.

Bernal S., Chillón L.A., Periodismo informativo de creación, Barcelona 1985.

Boo M.L., Galdós: periodismo y novela (La desheredada, La incógnita y tres artículos de La Prensa de Bunos Aires, „Anales galdosianos” 1988, vol. 23, s. 123-131.

Cadalso J., Cartas marruecas, ed. S. Fortuño Llorens, Barcelona 2000.

Cercas J., El impostor, Barcelona 2014.

Cercas J., Literatura más allá de la literatura, „El País”, 4.01.2015, http:/ / elpais.com/elpais/2015/01/02/eps/1420212864_912263.html.

Chillón L.A., La palabra facticia. Literatura, periodismo y comunicación, Valencia 2014.

Cruz Seoane M., Historia del periodismo en España, t. 2, Madrid 1983.

Davies R., Galdós y la prensa: hacia una revisión crítica de la mina inagotable, [w:] Actas del octavo congreso internacional de estudios galdosianos, Las Palmas 2005, s. 508-519.

El periodismo. Teoría y práctica, ed. N. González Ruiz, Barcelona 1953.

Estévez Molinero A., Relaciones entre literatura y periodismo: implicaciones históricas ( $y$ en páginas interiores, Larra, Galdós y Umbral), „Epos” 1998, vol. 14, s. 253-275.

García Osuna A.J., Novela en el tranvía: Galdós y la problematización del esquema discursivo del XIX, [w: ] Actas del noveno congreso internacional de estudios galdosianos, Las Palmas 2009, s. 288-293.

Głowiński M., Gry powieściowe. Szkice z teorii i historii form narracyjnych, Warszawa 1973.

Głowiński M., Powieść młodopolska. Studium z poetyki historycznej, Wrocław 1968.

Goytisolo J., El furgón de cola, Barcelona 1976.

Grossman D., Nuestra familia ha perdido la guerra, „El País”, 21.08.2006, http://elpais. com/diario/2006/08/21/opinion/1156111205_850215.html.

Hopfinger M., Wspótczesne przemiany literatury a dziennikarstwo, [w:] Dziennikarstwo a literatura w XX i XXI wieku, red. K. Wolny-Zmorzyński, W. Furman, J. Snopek, Warszawa 2011, s. 13-23.

Inman Fox E., El año 1898 y el origen de los intelectuales, [w:] J.L. Abellán et al., La crisis de fin de siglo: ideología y literatura. Estudios en memoria de R. Pérez de la Dehesa, Barcelona 1974, s. 17-24.

Javier Cercas sobre su novela El impostor, 10.12.2014, https://www.youtube.com/ watch?v=IW2UTu7Y8Ac.

Kłosińska-Nachin A., Miguel de Unamuno y el modernismo. Aproximación a la prosa unamuniana, Łódź 2012.

López Pan F., Periodismo literario: entre la literatura constitutiva y la condicional, „Ámbitos" 2010, vol. 19, s. 97-116.

Mancera Rueda A., El periodismo en las preceptivas literarias de los siglos XIX y XX, „Dicenda. Cuadernos de Filología Hispánica” 2011, vol. 29, s. 231-250.

Marías J., Así empieza lo malo, Madrid 2014.

Marías J., Los enamoramientos, Madrid 2011. 
Marías J., Negra espalda del tiempo, Madrid 1998.

Marín Malavé M.R., El columnismo de Juan José Millás en relación con su narrativa. Análisis de sus columnas en el País (1990-2018), Málaga 2011.

Martín Vivaldi G., Géneros periodísticos: Reportaje, crónica, artículo (Análisis diferencial), Madrid 1973.

Martínez Albertos J.L., La noticia y los comunicadores públicos, Madrid 1978.

Martínez Ruiz J., La ruta de don Quijote, Madrid 1998.

Millás J.J., Escribir, „El País”, 3.11.2000, http://elpais.com/diario/2000/11/03/ultima/973206002_850215.html.

Muñoz Molina A., Delibes, a lo lejos, „El País”, 20.03.2010, http://elpais.com/diario/2010/03/20/babelia/1269047536 850215.html.

Enciclopedia moderna. Diccionario universal de literatura, ciencias, artes, agricultura, industria y comercio, ed. F. de Paula Mellado, t. 30, Madrid 1954, s. 39-40.

Notatki z „Kurska”, http://www.rmf24.pl/fakty/news-notatki-z-kurska,nId,204864.

Pérez Galdós B., La novela en el tranvía, http://www.biblioteca.org.ar/libros/130023. pdf.

Pérez Galdós B., La sociedad presente como materia novelable, http://www.biblioteca.org. ar/libros/130020.pdf.

Ramos Corrada M., Periodismo y literatura en el XIX. El semanario „El Arte”, „Epos” 2000, vol. 16, s. 97-209.

Sánchez Sánchez J.F., Delibes: querido escritor incómodo, „Revista Cálamo FASPE” 2010, vol. 56, s. 51-52.

Sánchez Sánchez J.F., El novelista como trasunto del periodista, [w: ] Miguel Delibes. Nuevas lecturas críticas de su obra, ed. M. Pilar Celma Valero, M.J. Rodríguez Sánchez de León, Salamanca 2013, s. 115-125.

Villanueva D., Seis claves para Miguel Delibes, „El Cultural”, 15.03.2010, http://www.elcultural.com/noticias/letras/Seis-claves-para-Delibes/308. 